\title{
Genomics of autism spectrum disorder: approach to therapy
}

\section{[version 1; peer review: 3 approved]}

\author{
Fatma Ayhan, Genevieve Konopka
}

Department of Neuroscience, UT Southwestern Medical Center, Dallas, 75390-9111 TX, USA

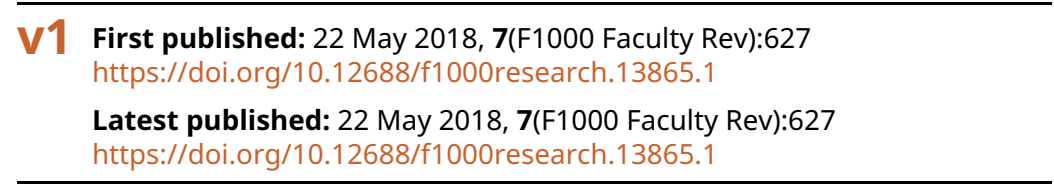

\section{Abstract}

Autism spectrum disorder (ASD) is a highly prevalent neurodevelopmental condition with no current treatment available. Although advances in genetics and genomics have identified hundreds of genes associated with ASD, very little is known about the pathophysiology of ASD and the functional contribution of specific genes to ASD phenotypes. Improved understanding of the biological function of ASD-associated genes and how this heterogeneous group of genetic variants leads to the disease is needed in order to develop therapeutic strategies. Here, we review the current state of ASD research related to gene discovery and examples of emerging molecular mechanisms (protein translation and alternative splicing). In addition, we discuss how patient-derived three-dimensional brain organoids might provide an opportunity to model specific genetic variants in order to define molecular and cellular defects that could be amenable for developing and screening personalized therapies related to ASD.

\section{Keywords}

autism, genomics, genetics, iPSCs, organoids, single-cell RNAsequencing

\section{Open Peer Review}

Approval Status

1

2 3

version 1

22 May 2018

Faculty Reviews are review articles written by the prestigious Members of Faculty Opinions. The articles are commissioned and peer reviewed before publication to ensure that the final, published version is comprehensive and accessible. The reviewers who approved the final version are listed with their names and affiliations.
1. Alysson R. Muotri (D), University of
California San Diego, La Jolla, USA University School of Medicine and Health Sciences, Washington, USA
3. Laia Rodriguez-Revenga, Hospital Clinic, Villarroel 170, Barcelona, Spain
2. M. Chiara Manzini, The George Washington Any comments on the article can be found at the end of the article. 
Corresponding author: Genevieve Konopka (genevieve.konopka@utsouthwestern.edu)

Author roles: Ayhan F: Conceptualization, Writing - Original Draft Preparation; Konopka G: Conceptualization, Writing - Review \& Editing

Competing interests: No competing interests were disclosed.

Grant information: This work is supported by grants from the National Institutes of Health (R01DC014702 and R01MH102603 to GK and T32DA007290-24 to FA), the Simons Foundation Autism Research Initiative (project 401220 to GK), and a James S. McDonnell Foundation 21st Century Science Initiative in Understanding Human Cognition - Scholar Award to GK. The funders had no role in study design, data collection and analysis, decision to publish, or preparation of the manuscript.

Copyright: ๑ 2018 Ayhan F and Konopka G. This is an open access article distributed under the terms of the Creative Commons Attribution License, which permits unrestricted use, distribution, and reproduction in any medium, provided the original work is properly cited. Data associated with the article are available under the terms of the Creative Commons Zero "No rights reserved" data waiver (CC0 1.0 Public domain dedication).

How to cite this article: Ayhan F and Konopka G. Genomics of autism spectrum disorder: approach to therapy [version 1; peer review: 3 approved] F1000Research 2018, 7(F1000 Faculty Rev):627 https://doi.org/10.12688/f1000research.13865.1

First published: 22 May 2018, 7(F1000 Faculty Rev):627 https://doi.org/10.12688/f1000research.13865.1 


\section{Introduction}

Autism spectrum disorder (ASD) is a phenotypically and genetically heterogeneous neurodevelopmental condition that manifests as deficits in reciprocal social interaction, repetitive behavior patterns, and restricted interests ${ }^{1}$. The prevalence of ASD is as high as 1 in 68 children $^{2}$ in the US, and ASD has a profound impact at the individual, family, and societal levels. Although environmental factors likely play some role in the etiology of $\mathrm{ASD}^{3}$, family and twin studies show that genetics contribute to the majority of the risk associated with $\mathrm{ASD}^{4-9}$. Genome-wide studies using genotyping microarrays, whole exome sequencing (WES), and whole genome sequencing have identified a rapidly growing number of genes linked to $\mathrm{ASD}^{10-21}$, providing a window into the molecular underpinnings of the disorder. However, our understanding of molecular mechanisms anchored to this heterogeneous group of genetic variants is not entirely clear. The paucity of disease-modifying therapies or molecular diagnostic tools for ASD makes identifying molecular disease mechanisms critical to assist developing rationally designed therapies. Additionally, details regarding the time course of molecular alterations in ASD can inform diagnostic biomarkers and quantitative measures to indicate disease severity and evaluate the efficacy of future therapeutic approaches.

Here, we review the recent progress in understanding the underlying genetics of ASD, including the identification of inherited, de novo, and somatic mutations linked to the disease. We then discuss how convergent disease mechanisms in ASD can potentially translate into the most appropriate biomarker development and treatment strategies for individuals or subtypes (or both) with ASD. Finally, we consider the unprecedented premise of patient-derived three-dimensional (3D) brain organoids as appropriate models to test and validate the functional impact of identified genetic variants as accessible and flexible platforms to screen and test for therapeutic agents.

\section{The complex genetic makeup of autism spectrum disorder}

The importance of heritable genetic variability in ASD pathogenesis has been highlighted in twin and family studies. The increased prevalence of the disease in siblings of ASD patients and greater ASD concordance rates in monozygotic twins compared with dizygotic twins has prompted significant efforts toward understanding the genetic architecture of ASD pathophysiology. Although the identification of mutations linked to monogenic syndromic forms of ASD, including Fragile $\mathrm{X}^{22}$, Rett $^{23}, M E C P 2$ duplication ${ }^{24}$, tuberous sclerosis complex ${ }^{25}, P T E N$ macrocephaly ${ }^{26}$, and Timothy ${ }^{27}$ syndromes, provided key insights into the genetic basis of ASD, these rare syndromes collectively account for only about $5 \%$ of ASD cases $^{28}$, leaving the etiology of non-syndromic ASD cases mostly unknown. The highly heterogeneous disease presentation of non-syndromic ASD initially posed serious impediments for identifying reproducible ASD-associated mutations. Despite these challenges, the assembly of large patient cohorts along with advances in genomic technologies within the last decade has facilitated the identification of ASD-associated variants in hundreds of genes, including single-nucleotide variant (SNVs) and copy number variants $(\mathrm{CNVs})^{29}$. The use of WES and whole genome sequencing in family cohorts with sporadic ASD (simplex) and with more than one affected individual (multiplex) led to the discovery of both rare inherited and de novo ASD risk variants. Rare recessive mutations have been reported in genes such as $C N T N A P 2^{30}$, $S L C 9 A 9^{31}, A M T^{20}, P E X 7^{20}, C C 2 D 1 A^{32}$, and $B C K D K^{33}$ in consanguineous families with ASD and epilepsy, highlighting the role of recessive inheritance of deleterious mutations associated with ASD. The role of inherited variants in ASD was further supported through WES in larger cohorts of unrelated families ${ }^{34,35}$. WES in large cohorts of simplex families (one affected child sequenced together with unaffected parents) provided substantial insight into the role of de novo (or spontaneous) genetic variants in ASD. Numerous studies have reported increased rates of rare de novo $\mathrm{CNV}$ s and $\mathrm{SNVs}$ in individuals with $\mathrm{ASD}^{10,16-18,36}$ and have identified high-confidence ASD genes, including CHD $8^{16,18,37-39}$, SYNGAP1 $1^{21,40,41}, D Y R K 1 A^{42}$, and $S C N 2 A^{16}$. Moreover, targeted sequencing approaches confirmed the recurrence of some of these de novo mutations in independent cohorts, substantiating their role in ASD pathogenesis ${ }^{10,36,39}$. Finally, one very interesting group of genetic variants that has recently been implicated in ASD is somatic mutations ${ }^{43-45}$. Somatic mutations can occur during development and yield mosaic individuals with distinct cellular genomes in subsets of their somatic cells ${ }^{46}$. Whereas routine genetic sampling from blood misses the disease-associated somatic variants in the brain, targeted sequencing on ASD post-mortem tissue has detected increased rates of deleterious somatic mutations in cases compared with controls ${ }^{45}$. Interestingly, there may be some overlap of genes at risk for both germline and de novo somatic mutations (for example, $S C N 2 A)^{43}$. Future single-cell sequencing approaches ${ }^{47}$ will be informative to identify and characterize cells that carry disease-related somatic mutations ${ }^{48}$.

Taken together, recent advances in ASD gene discovery highlight the complexity of the genetic landscape of the disease while beginning to shed light on some of the biological pathways at risk in ASD. This complexity is underscored by the potential for certain combinations of common genetic variants contributing to ASD by increasing an individual's susceptibility to pathogenic effects of rare inherited, de novo, or somatic mutations. Given the progress in identifying high-confidence risk genes for ASD, investigators can now direct their attention to understanding the pathogenicity of this genetic variance and identifying potential common convergent disease mechanisms as molecular targets for future treatment strategies.

\section{Convergent molecular mechanisms}

One approach to understand pathogenesis and identify therapeutic targets amid a complex genetic architecture is to elucidate downstream pathways commonly affected across ASD cases with distinct genetic etiologies. One example of a convergent molecular mechanism includes defects in the regulation of protein synthesis and alternative splicing (AS) as potential unifying pathways for $\mathrm{ASD}^{49}$.

Precise regulation of translation at synapses during the tight window of a learning experience has been shown to be extremely critical for the formation and maintenance of long-term 
memory ${ }^{50}$. Several mutations in translation factors and regulators such as $e I F 4 E^{51,52}, T S C 1 / 2^{53}$, and $P T E N^{54}$ are associated with ASD, underscoring the involvement of translational defects in ASD pathogenesis. Furthermore, there is emerging evidence showing dysregulated translational activity in cells derived from non-syndromic ASD patients, including aberrant activity of mammalian target of rapamycin (mTOR), a key regulator of translation, suggesting translational dysregulation as a shared pathogenic mechanism in genetically distinct ASD cases ${ }^{55,56}$. The inhibition of aberrant translation directly via compounds targeting translation factors (for example, 4EGI- ${ }^{57}$ ) or by modulating the mTOR pathway ${ }^{58}$ has been shown to prevent autism-relevant phenotypes in mice and has been proposed as a therapeutic strategy to correct dysregulated protein synthesis in $\mathrm{ASD}^{58}$.

AS is co- or post-transcriptionally regulated by RNA-binding proteins (RBPs) and tightly controlled during developmental stages in a tissue-specific manner ${ }^{59}$. Given the limited number of protein-coding genes in the human genome, AS is recognized as an essential source of transcriptomic and proteomic diversity driving the species-specific features of the human brain $^{60-62}$. Dysregulation of AS in post-mortem brain tissue from ASD patients with distinct etiologies has been increasingly apparent as a convergent mechanism in $\mathrm{ASD}^{63-65}$. The transcripts that are misspliced in ASD are enriched for neuronal RBP targets, including those of RBFOX $1^{63,65}$, SRRM $4{ }^{65}$, and PTBP $1^{65}$, suggesting that defective RBP function is a common feature of ASD. Genetic evidence showing ASD-linked chromosomal translocations and copy number variations in RBFOX1 also supports a prominent role for loss or dysregulation (or both) of RBFOX1 activity in ASD pathogenesis ${ }^{13,66-68}$. Loss of RBFOX1 in mice causes deficits in synaptic transmission ${ }^{69}$ and corticogenesis ${ }^{70}$. Neuronal-specific, activity-dependent, 3- to 27-nucleotide microexons are frequently misspliced in $\mathrm{ASD}^{64,71}$. This group of genes that are subject to microexon splicing is enriched for synaptic functions and ASD genes ${ }^{64,71}$. These microexons are regulated primarily by the neuronal RBP, SRRM4, which is downregulated in ASD brains ${ }^{64}$. Haploinsufficiency of SRRM4 in mice resulted in microexon misregulation and ASD-like features, including altered social behaviors ${ }^{71}$. These data highlight the function of RBPs, including RBFOX1 and SRRM4, as essential for cortical development and function and at risk in ASD. Taken together, global dysregulation of RNA processing and protein translation is likely to be a common feature of genetically diverse ASD cases, and the regulation of these processes might be a viable target for therapeutic approaches.

\section{Patient-specific disease models}

The high degree of genetic heterogeneity in ASD requires personalized approaches to understand the underlying individual pathogenic mechanisms and develop efficient treatments. In addition, there is a need for improved model systems with appropriate genetic backgrounds to test identified convergent biological mechanisms such as the ones discussed above. Advances in stem cell biology in the last decade have yielded protocols for the generation of human neurons from accessible somatic tissue (for example, skin), overcoming the unavailability of human neurons from specific developmental stages or disease states.
Briefly, human induced pluripotent stem cells (hiPSCs) are generated by the ectopic expression of specific transcription factors in somatic cells that then can be differentiated into neurons or glia harboring the genetic features of the human individual from whom the cells are derived, either the patients or matched unaffected controls ${ }^{72}$. In addition, isogenic neurons generated by introducing mutations in control iPSCs via gene editing technologies - that is, CRISPR-Cas $9^{73,74}$ and TALENs ${ }^{75}$ can be used to study the functional impact of disease-related mutations on a non-disease genetic background.

Research adopting iPSC-based models has begun to impact the understanding of the biological underpinnings of several ASD-related genetic variants ${ }^{76,77}$. In several instances, syndromic forms of ASD, including Fragile $X^{78,79}$, Rett ${ }^{80}$, Timothy ${ }^{81,82}$, and Phelan-McDermid ${ }^{83}$ syndromes, have been modeled by using iPSCs. These studies have defined disease-related defects in patient-derived neurons, including reduced synaptic density, impaired excitatory transmission, and aberrant signaling. Additionally, a recent study of iPSCs from an ASD patient with a de novo mutation in TRPC6 confirmed the potential for patientspecific disease modeling of rare ASD variants ${ }^{84}$.

Breakthroughs in iPSC culture systems have facilitated the generation of more complex differentiation programs that yield organ-like structures. These 3D brain organoids have been established with the goal of improved recapitulation of brain development and connectivity in vitro, providing an unprecedented opportunity to study human brain features in a dish ${ }^{85-87}$. A major goal of using patient-derived 3D organoids is to perform highthroughput drug screens to correct ASD-relevant cellular defects and reliably predict drug responses specific to each individual. In the future, standardization of 3D human brain organoid generation is needed for reliable and reproducible disease modeling. Defining the functional properties and molecular signatures of brain organoids derived from unaffected iPSCs at several time points will provide insights into how this model system follows in vivo human brain development and baseline information for disease modeling. It will be important to address how the differentiation process of 3D brain organoids corresponds to stages of human brain development. This will be essential to identify and translate the critical time window for successful therapeutic intervention. Recent advances in single-cell RNA sequencing facilitate the identification of cell types and differentiation states of diverse human neuronal populations in fetal brain in vivo ${ }^{88}$ and have also proven to be very useful for characterizing brain organoids ${ }^{89}$. Integration of cell-specific gene expression profiles with regional and developmental timing mechanisms has been elegantly carried out from human fetal tissue ${ }^{88}$, and these data can be superimposed on the data derived from patient organoids to identify aberrant profiles. Inherent limitations of 3D brain organoids such as lack of behavioral output and circuit-based studies should be addressed with complementary studies using animal models ${ }^{19}$.

In terms of cell-specific profiling, most research has gone into characterizing the neuronal defects in ASD; however, the involvement of glia has recently been implicated in many neuropsychiatric diseases ${ }^{90}$. For example, a recent iPSC model 
provided evidence that defects in astrocytes can contribute to non-syndromic ASD $^{91}$ with unknown genetic cause. Therefore, future strategies to develop therapies for ASD should not only focus on neurons but also include all cell types in the brain. In addition, these data support the promise of using iPSC models from individuals with genetically complex etiologies to narrow the therapeutic search window to common pathogenic mechanisms. Improvements to brain organoid models that include many cell types such as glia and endothelial cells from non-syndromic ASD patients should further facilitate the identification of patient-specific cellular deficits.

\section{Conclusions}

Technological and conceptual advances in genomics, stem cell biology, and gene editing together with large cohorts of patients are providing opportunities to identify genetic causes of ASD and develop functionally relevant disease models. Integrative studies that include post-mortem tissue, genomics, and singlecell transcriptomics will continue to provide insights into human brain development and how this process is disrupted in ASD. By improved modeling of the disease using patient tissues and incorporating data from genomic and gene expression studies into these models, the field should move closer to developing personalized therapeutic approaches as well as identifying common druggable molecular pathways. Thus, persistent pursuit of all of the strategies discussed above will be needed to define optimal personalized treatments that potentially could involve several drugs in combination for additive or synergistic effects.

\section{Abbreviations}

3D, three-dimensional; AS, alternative splicing; ASD, autism spectrum disorder; CNV, copy number variant; hiPSC, human induced pluripotent stem cell; mTOR, mammalian target of rapamycin; RBP, RNA-binding protein; SNV, single-nucleotide variant; WES, whole exome sequencing.

\section{Competing interests}

The authors declare that they have no competing interests.

\section{Grant information}

This work is supported by grants from the National Institutes of Health (R01DC014702 and R01MH102603 to GK and T32DA007290-24 to FA), the Simons Foundation Autism Research Initiative (project 401220 to GK), and a James S. McDonnell Foundation 21st Century Science Initiative in Understanding Human Cognition - Scholar Award to GK.

The funders had no role in study design, data collection and analysis, decision to publish, or preparation of the manuscript.

\section{Acknowledgments}

The authors wish to thank Maria Chahrour for her helpful comments and suggestions. GK is a Jon Heighten Scholar in Autism Research at UT Southwestern.
1. American Psychiatric Association: Diagnostic and Statistical Manual of Mental Disorders: DSM-5. 5th edn. American Psychiatric Association, Arlington, Virginia, USA 2013.

Publisher Full Text

2. Christensen DL, Baio J, Van Naarden Braun K, et al.: Prevalence and Characteristics of Autism Spectrum Disorder Among Children Aged 8 Years-Autism and Developmental Disabilities Monitoring Network, 11 Sites, United States, 2012. MMWR Surveill Summ. 2016; 65(3): 1-23. PubMed Abstract | Publisher Full Text

3. Kim YS, Leventhal BL: Genetic epidemiology and insights into interactive genetic and environmental effects in autism spectrum disorders. Biol Psychiatry. 2015; 77(1): 66-74. PubMed Abstract | Publisher Full Text | Free Full Text

4. Rosenberg RE, Law JK, Yenokyan G, et al:: Characteristics and concordance of autism spectrum disorders among 277 twin pairs. Arch Pediatr Adolesc Med. 2009; 163(10): 907-14. PubMed Abstract | Publisher Full Text

5. Bailey A, Le Couteur A, Gottesman I, et al:: Autism as a strongly genetic disorder: evidence from a British twin study. Psychol. Med. 1995; 25(1): 63-77. PubMed Abstract | Publisher Full Text

6. F Ozonoff S, Young GS, Carter A, et al:: Recurrence risk for autism spectrum disorders: a Baby Siblings Research Consortium study. Pediatrics. 2011; 128(3): e488-95.

PubMed Abstract | Publisher Full Text | Free Full Text | F1000 Recommendation

7. F Hallmayer J, Cleveland S, Torres A, et al: Genetic heritability and shared environmental factors among twin pairs with autism. Arch Gen Psychiatry. 2011; 68(11): 1095-102.

PubMed Abstract | Publisher Full Text | Free Full Text | F1000 Recommendation

8. Sandin $\mathrm{S}$, Lichtenstein $\mathrm{P}$, Kuja-Halkola $\mathrm{R}$, et al:: The familial risk of autism. JAMA. 2014; 311(17): 1770-7.

PubMed Abstract | Publisher Full Text | Free Full Text

9. Colvert E, Tick B, McEwen F, et al:: Heritability of Autism Spectrum Disorder in a UK Population-Based Twin Sample. JAMA Psychiatry. 2015; 72(5): 415-23. PubMed Abstract | Publisher Full Text | Free Full Text

10. De Rubeis S, He X, Goldberg AP, et al.: Synaptic, transcriptional and chromatin genes disrupted in autism. Nature. 2014; 515(7526): 209-15. PubMed Abstract | Publisher Full Text | Free Full Text

11. Gaugler T, Klei L, Sanders SJ, et al.: Most genetic risk for autism resides with common variation. Nat Genet. 2014; 46(8): 881-5. PubMed Abstract | Publisher Full Text | Free Full Text

12. C Yuen RK, Merico D, Bookman M, et al:: Whole genome sequencing resource identifies 18 new candidate genes for autism spectrum disorder. Nat Neurosci. 2017; 20(4): 602-11.

PubMed Abstract | Publisher Full Text | Free Full Text

13. F Sebat J, Lakshmi B, Malhotra D, et al.: Strong association of de novo copy number mutations with autism. Science. 2007; 316(5823): 445-9. PubMed Abstract | Publisher Full Text | Free Full Text | F1000 Recommendation

14. F Sanders SJ, Ercan-Sencicek AG, Hus V, et al:: Multiple recurrent de novo CNVs, including duplications of the 7q11.23 Williams syndrome region, are strongly associated with autism. Neuron. 2011; 70(5): 863-85. PubMed Abstract | Publisher Full Text | Free Full Text | F1000 Recommendation

15. Gilman SR, lossifov I, Levy D, et al.: Rare de novo variants associated with autism implicate a large functional network of genes involved in formation and function of synapses. Neuron. 2011; 70(5): 898-907. PubMed Abstract | Publisher Full Text | Free Full Text

16. F Sanders SJ, Murtha MT, Gupta AR, et al.: De novo mutations revealed by whole-exome sequencing are strongly associated with autism. Nature. 2012; whole-exome sequencing are strongly associated with autism. Nature. 2012;
PubMed Abstract | Publisher Full Text | Free Full Text | F1000 Recommendation

17. Iossifov I, Ronemus M, Levy D, et al:: De novo gene disruptions in children on the autistic spectrum. Neuron. 2012; 74(2): 285-99. PubMed Abstract | Publisher Full Text | Free Full Text

18. Neale BM, Kou $Y$, Liu L et al: Patterns and rates of exonic de novo mutations in 
autism spectrum disorders. Nature. 2012; 485(7397): 242-5 PubMed Abstract | Publisher Full Text | Free Full Text

19. Chahrour M, O'Roak BJ, Santini E, et al.: Current Perspectives in Autism Spectrum Disorder: From Genes to Therapy. J Neurosci. 2016; 36(45): 11402-10. PubMed Abstract | Publisher Full Text | Free Full Text

20. Yu TW, Chahrour MH, Coulter ME, et al.: Using whole-exome sequencing to identify inherited causes of autism. Neuron. 2013; 77(2): 259-73. PubMed Abstract | Publisher Full Text | Free Full Text

21. O'Roak BJ, Stessman HA, Boyle EA, et al.: Recurrent de novo mutations implicate novel genes underlying simplex autism risk. Nat Commun. 2014; 5: 5595. PubMed Abstract | Publisher Full Text | Free Full Text

22. Verkerk AJ, Pieretti M, Sutcliffe JS, et al.: Identification of a gene (FMR-1) containing a CGG repeat coincident with a breakpoint cluster region exhibiting length variation in fragile X syndrome. Cell. 1991; 65(5): 905-14. PubMed Abstract | Publisher Full Text

23. Amir RE, Van den Veyver IB, Wan M, et al.: Rett syndrome is caused by mutations in X-linked MECP2, encoding methyl-CpG-binding protein 2. Nat Genet. 1999; 23(2): 185-8.

PubMed Abstract | Publisher Full Text

24. F Van Esch H, Bauters M, Ignatius J, et al:: Duplication of the MECP2 region is a frequent cause of severe mental retardation and progressive neurological symptoms in males. Am J Hum Genet. 2005; 77(3): 442-53. PubMed Abstract | Publisher Full Text | Free Full Text | F1000 Recommendation

25. Fryer AE, Chalmers A, Connor JM, et al:: Evidence that the gene for tuberous sclerosis is on chromosome 9. Lancet. 1987; 1(8534): 659-61. PubMed Abstract | Publisher Full Text

26. Butler MG, Dasouki MJ, Zhou XP, et al:: Subset of individuals with autism spectrum disorders and extreme macrocephaly associated with germline PTEN tumour suppressor gene mutations. J Med Genet. 2005; 42(4): 318-21. PubMed Abstract | Publisher Full Text | Free Full Text

27. F Splawski I, Timothy KW, Sharpe LM, et al.: $\mathrm{Ca}_{\mathrm{v}} \mathbf{1 . 2}$ calcium channel dysfunction causes a multisystem disorder including arrhythmia and autism. Cell. 2004; 119(1): 19-31.

PubMed Abstract | Publisher Full Text | F1000 Recommendation

28. F Sztainberg $Y$, Zoghbi $H Y$ : Lessons learned from studying syndromic autism spectrum disorders. Nat Neurosci. 2016; 19(11): 1408-17. PubMed Abstract | Publisher Full Text | F1000 Recommendation

29. Geschwind DH, State MW: Gene hunting in autism spectrum disorder: On the path to precision medicine. Lancet Neurol. 2015; 14(11): 1109-20. PubMed Abstract | Publisher Full Text | Free Full Text

30. F Strauss KA, Puffenberger EG, Huentelman MJ, et al.: Recessive symptomatic focal epilepsy and mutant contactin-associated protein-like 2. N Engl J Med. 2006; 354(13): 1370-7.

PubMed Abstract | Publisher Full Text | F1000 Recommendation

31. F Morrow EM, Yoo SY, Flavell SW, et al:: Identifying autism loci and genes by tracing recent shared ancestry. Science. 2008; 321(5886): 218-23. PubMed Abstract | Publisher Full Text | Free Full Text | F1000 Recommendation

32. Manzini MC, Xiong L, Shaheen $\mathrm{R}$, et al:: CC2D1A regulates human intellectua and social function as well as NF-кB signaling homeostasis. Cell Rep. 2014 8(3): $647-55$

PubMed Abstract | Publisher Full Text | Free Full Text

33. F Novarino G, El-Fishawy $\mathrm{P}$, Kayserili $\mathrm{H}$, et al:: Mutations in BCKD-kinase lead to a potentially treatable form of autism with epilepsy. Science. 2012 338(6105): 394-7.

PubMed Abstract | Publisher Full Text | Free Full Text | F1000 Recommendation

34. Chahrour MH, Yu TW, Lim ET, et al:: Whole-exome sequencing and homozygosity analysis implicate depolarization-regulated neuronal genes in autism. PLoS Genet. 2012; 8(4): e1002635.

PubMed Abstract | Publisher Full Text | Free Full Text

35. F Lim ET, Raychaudhuri S, Sanders SJ, et al:: Rare complete knockouts in humans: population distribution and significant role in autism spectrum disorders. Neuron. 2013; 77(2): 235-42.

PubMed Abstract | Publisher Full Text | Free Full Text | F1000 Recommendation

36. Iossifov I, O'Roak BJ, Sanders SJ, et al.: The contribution of de novo coding mutations to autism spectrum disorder. Nature. 2014; 515(7526): 216-21. PubMed Abstract | Publisher Full Text | Free Full Text

37. F O'Roak BJ, Vives L, Girirajan S, et al.: Sporadic autism exomes reveal a highly interconnected protein network of de novo mutations. Nature. 2012; 485(7397): 246-50.

PubMed Abstract | Publisher Full Text | Free Full Text | F1000 Recommendation

38. F Bernier R, Golzio C, Xiong B, et al.: Disruptive CHD8 mutations define a subtype of autism early in development. Cell. 2014; 158(2): 263-76. PubMed Abstract | Publisher Full Text | Free Full Text | F1000 Recommendation

39. F O'Roak BJ, Vives L, Fu W, et al:: Multiplex targeted sequencing identifies recurrently mutated genes in autism spectrum disorders. Science. 2012; 338(6114): 1619-22.

PubMed Abstract | Publisher Full Text | Free Full Text | F1000 Recommendation

40. Hamdan FF, Daoud H, Piton A, et al:: De novo SYNGAP1 mutations in nonsyndromic intellectual disability and autism. Biol Psychiatry. 2011; 69(9):
898-901

PubMed Abstract | Publisher Full Tex

41. Parker MJ, Fryer AE, Shears DJ, et al:: De novo, heterozygous, loss-of-function mutations in SYNGAP1 cause a syndromic form of intellectual disability. Am J Med Genet A. 2015; 167A(10): 2231-7.

PubMed Abstract | Publisher Full Text | Free Full Text

42. van Bon BW, Coe BP, Bernier R, et al:: Disruptive de novo mutations of DYRK1A lead to a syndromic form of autism and ID. Mol Psychiatry. 2016; 21(1): 126-32. PubMed Abstract | Publisher Full Text | Free Full Text

43. F Lim ET, Uddin M, De Rubeis S, et al:: Rates, distribution and implications of postzygotic mosaic mutations in autism spectrum disorder. Nat Neurosci. 2017; 20(9): 1217-24.

PubMed Abstract | Publisher Full Text | Free Full Text | F1000 Recommendation

44. F Krupp DR, Barnard RA, Duffourd Y, et al.: Exonic Mosaic Mutations Contribute Risk for Autism Spectrum Disorder. Am J Hum Genet. 2017; 101(3): 369-90. PubMed Abstract | Publisher Full Text | Free Full Text | F1000 Recommendation

45. F D'Gama AM, Pochareddy S, Li M, et al:: Targeted DNA Sequencing from Autism Spectrum Disorder Brains Implicates Multiple Genetic Mechanisms. Neuron. 2015; 88(5): 910-7.

PubMed Abstract | Publisher Full Text | Free Full Text | F1000 Recommendation

46. Poduri A, Evrony GD, Cai X, et al:: Somatic mutation, genomic variation, and neurological disease. Science. 2013; 341(6141): 1237758. PubMed Abstract | Publisher Full Text | Free Full Text

47. F Poulin JF, Tasic B, Hjerling-Leffler J, et al:: Disentangling neural cell diversity using single-cell transcriptomics. Nat Neurosci. 2016; 19(9): 1131-41. PubMed Abstract | Publisher Full Text | F1000 Recommendation

48. McConnell MJ, Moran JV, Abyzov A, et al.: Intersection of diverse neuronal genomes and neuropsychiatric disease: The Brain Somatic Mosaicism Network. Science. 2017; 356(6336): pii: eaal1641. PubMed Abstract | Publisher Full Text | Free Full Text

49. de la Torre-Ubieta L, Won H, Stein JL, et al:: Advancing the understanding of autism disease mechanisms through genetics. Nat Med. 2016; 22(4): 345-61. PubMed Abstract | Publisher Full Text | Free Full Text

50. Buffington SA, Huang W, Costa-Mattioli M: Translational control in synaptic plasticity and cognitive dysfunction. Annu Rev Neurosci. 2014; 37: 17-38. PubMed Abstract | Publisher Full Text | Free Full Text

51. F Autism Genome Project Consortium, Szatmari P, Paterson AD, et al:: Mapping autism risk loci using genetic linkage and chromosomal rearrangements. Nat Genet. 2007; 39(3): 319-28.

PubMed Abstract | Publisher Full Text | Free Full Text | F1000 Recommendation

52. Yonan AL, Alarcón M, Cheng R, et al:: A genomewide screen of $\mathbf{3 4 5}$ families for autism-susceptibility loci. Am J Hum Genet. 2003; 73(4): 886-97. PubMed Abstract | Publisher Full Text | Free Full Text

53. Jeste SS, Sahin M, Bolton $\mathrm{P}$, et al:: Characterization of autism in young children with tuberous sclerosis complex. J Child Neurol. 2008; 23(5): 520-5. PubMed Abstract | Publisher Full Text

54. Krumm N, O'Roak BJ, Shendure J, et al:: A de novo convergence of autism genetics and molecular neuroscience. Trends Neurosci. 2014; 37(2): 95-105. PubMed Abstract | Publisher Full Text | Free Full Text

55. F Suzuki AM, Griesi-Oliveira K, de Oliveira Freitas Machado C, et al:: Altered mTORC1 signaling in multipotent stem cells from nearly $25 \%$ of patients with nonsyndromic autism spectrum disorders. Mol Psychiatry. 2015; 20(5): 551-2. PubMed Abstract | Publisher Full Text | F1000 Recommendation

56. F Poopal AC, Schroeder LM, Horn PS, et al:: Increased expression of the PI3K catalytic subunit p110 $\delta$ underlies elevated S6 phosphorylation and protein synthesis in an individual with autism from a multiplex family. Mol Autism. 2016; 7: 3.

PubMed Abstract | Publisher Full Text | Free Full Text | F1000 Recommendation

57. Santini E, Huynh TN, MacAskill AF, et al.: Exaggerated translation causes synaptic and behavioural aberrations associated with autism. Nature. 2013; 493(7432): 411-5.

PubMed Abstract | Publisher Full Text | Free Full Text

58. F Tsai PT, Hull C, Chu Y, et al.: Autistic-like behaviour and cerebellar dysfunction in Purkinje cell Tsc1 mutant mice. Nature. 2012; 488(7413): 647-51. PubMed Abstract | Publisher Full Text | Free Full Text | F1000 Recommendation

59. Scotti MM, Swanson MS: RNA mis-splicing in disease. Nat Rev Genet. 2016; 17(1): 19-32.

PubMed Abstract | Publisher Full Text

60. Pan $Q$, Shai $O$, Lee LJ, et al.: Deep surveying of alternative splicing complexity in the human transcriptome by high-throughput sequencing. Nat Genet. 2008 40(12): 1413-5.

PubMed Abstract | Publisher Full Text

61. Lin L, Shen S, Jiang $P$, et al.: Evolution of alternative splicing in primate brain transcriptomes. Hum Mol Genet. 2010; 19(15): 2958-73. PubMed Abstract | Publisher Full Text | Free Full Text

62. F Wang ET, Sandberg R, Luo S, et al:: Alternative isoform regulation in human tissue transcriptomes. Nature. 2008; 456(7221): 470-6. PubMed Abstract | Publisher Full Text | Free Full Text | F1000 Recommendation

63. $\mathrm{F}$ Voineagu I, Wang $\mathrm{X}$, Johnston $\mathrm{P}$, et al:: Transcriptomic analysis of autistic 
brain reveals convergent molecular pathology. Nature. 2011; 474(7351): 380-4. PubMed Abstract | Publisher Full Text | Free Full Text | F1000 Recommendation

64. F Irimia M, Weatheritt RJ, Ellis JD, et al:: A highly conserved program of neuronal microexons is misregulated in autistic brains. Cell. 2014; 159(7): 1511-23. PubMed Abstract | Publisher Full Text | Free Full Text | F1000 Recommendation

65. Parikshak NN, Swarup V, Belgard TG, et al:: Genome-wide changes in IncRNA, splicing, and regional gene expression patterns in autism. Nature. 2016 540(7633): 423-7.

PubMed Abstract | Publisher Full Text

66. Martin $\mathrm{CL}$, Duvall JA, Ilkin Y, et al.: Cytogenetic and molecular characterization of A2BP1/FOX1 as a candidate gene for autism. Am J Med Genet B Neuropsychiatr Genet. 2007; 144B(7): 869-76. PubMed Abstract | Publisher Full Text

67. Mikhail FM, Lose EJ, Robin NH, et al:: Clinically relevant single gene or intragenic deletions encompassing critical neurodevelopmental genes in patients with developmental delay, mental retardation, and/or autism spectrum disorders. Am J Med Genet A. 2011; 155A(10): 2386-96. PubMed Abstract | Publisher Full Text

68. Davis LK, Maltman N, Mosconi MW, et al: Rare inherited A2BP1 deletion in a proband with autism and developmental hemiparesis. Am J Med Genet A. 2012; 158A(7): 1654-61.

PubMed Abstract | Publisher Full Text | Free Full Text

69. Gehman LT, Stoilov P, Maguire J, et al:: The splicing regulator Rbfox1 (A2BP1) controls neuronal excitation in the mammalian brain. Nat Genet. 2011; 43(7): 706-11.

PubMed Abstract | Publisher Full Text | Free Full Text

70. Hamada N, Ito H, Iwamoto I, et al.: Role of the cytoplasmic isoform of RBFOX1/ A2BP1 in establishing the architecture of the developing cerebral cortex. Mol Autism. 2015; 6: 56

PubMed Abstract | Publisher Full Text | Free Full Text

71. F Quesnel-Vallières $\mathrm{M}$, Dargaei Z, Irimia $\mathrm{M}$, et al:: Misregulation of an ActivityDependent Splicing Network as a Common Mechanism Underlying Autism Spectrum Disorders. Mol Cell. 2016; 64(6): 1023-34. PubMed Abstract | Publisher Full Text | F1000 Recommendation

72. Pașca SP, Panagiotakos G, Dolmetsch RE: Generating human neurons in vitro and using them to understand neuropsychiatric disease. Annu Rev Neurosci. 2014; 37: 479-501.

PubMed Abstract | Publisher Full Text

73. F Le Cong, Ran FA, Cox D, et al:: Multiplex genome engineering using CRISPR/Cas systems. Science. 2013; 339(6121): 819-23.

PubMed Abstract | Publisher Full Text | Free Full Text | F1000 Recommendation

74. $\mathrm{F}$ Mali $\mathrm{P}$, Yang L, Esvelt KM, et al.: RNA-guided human genome engineering via Cas9. Science. 2013; 339(6121): 823-6.

PubMed Abstract | Publisher Full Text | Free Full Text | F1000 Recommendation

75. Miller JC, Tan S, Qiao G, et al.: A TALE nuclease architecture for efficient genome editing. Nat Biotechnol. 2011; 29(2): 143-8.

PubMed Abstract | Publisher Full Text

76. F Nestor MW, Phillips AW, Artimovich E, et al:: Human Inducible Pluripotent Stem Cells and Autism Spectrum Disorder: Emerging Technologies. Autism Res. 2016; 9(5): 513-35.

PubMed Abstract | Publisher Full Text | F1000 Recommendation

77. F Beltrão-Braga PC, Muotri AR: Modeling autism spectrum disorders with human neurons. Brain Res. 2017: 1656: 49-54.

PubMed Abstract | Publisher Full Text | Free Full Text | F1000 Recommendation
78. Liu J, Koscielska KA, Cao Z, et al.: Signaling defects in iPSC-derived fragile $\mathbf{X}$ premutation neurons. Hum Mol Genet. 2012; 21(17): 3795-805.

PubMed Abstract | Publisher Full Text | Free Full Text

79. Doers ME, Musser MT, Nichol R, et al:: iPSC-derived forebrain neurons from FXS individuals show defects in initial neurite outgrowth. Stem Cells Dev. 2014 23(15): 1777-87.

PubMed Abstract | Publisher Full Text | Free Full Text

80. F Marchetto MC, Carromeu C, Acab A, et al.: A model for neural development and treatment of Rett syndrome using human induced pluripotent stem cells. Cell. 2010; 143(4): 527-39.

PubMed Abstract | Publisher Full Text | Free Full Text | F1000 Recommendation

81. Tian Y, Voineagu I, Paşca SP, et al.: Alteration in basal and depolarization induced transcriptional network in iPSC derived neurons from Timothy syndrome. Genome Med. 2014; 6(10): 75

PubMled Abstract | Publisher Full Text | Free Full Text

82. Krey JF, Paşca SP, Shcheglovitov A, et al:: Timothy syndrome is associated with activity-dependent dendritic retraction in rodent and human neurons. Nat Neurosci. 2013; 16(2): 201-9.

PubMed Abstract | Publisher Full Text | Free Full Text

83. F Shcheglovitov A, Shcheglovitova O, Yazawa M, et al:: SHANK3 and IGF1 restore synaptic deficits in neurons from 22q13 deletion syndrome patients. Nature. 2013; 503(7475): 267-71.

PubMed Abstract | Publisher Full Text | Free Full Text | F1000 Recommendation

84. F Griesi-Oliveira K, Acab A, Gupta AR, et al:: Modeling non-syndromic autism and the impact of TRPC6 disruption in human neurons. Mol Psychiatry. 2015; 20(11): 1350-65.

PubMed Abstract | Publisher Full Text | Free Full Text | F1000 Recommendation

85. Lancaster MA, Knoblich JA: Generation of cerebral organoids from human pluripotent stem cells. Nat Protoc. 2014; 9(10): 2329-40. PubMed Abstract | Publisher Full Text | Free Full Text

86. Giandomenico SL, Lancaster MA: Probing human brain evolution and development in organoids. Curr Opin Cell Biol. 2017; 44: 36-43. PubMed Abstract | Publisher Full Text

87. Camp JG, Treutlein B: Human organomics: a fresh approach to understanding human development using single-cell transcriptomics. Development. 2017; 144(9): 1584-7.

PubMed Abstract | Publisher Full Text

88. F Nowakowski TJ, Bhaduri A, Pollen AA, et al:: Spatiotemporal gene expression trajectories reveal developmental hierarchies of the human cortex. Science. 2017; 358: 1318-23.

PubMed Abstract | Publisher Full Text | F1000 Recommendation

89. F Camp JG, Badsha F, Florio M, et al.: Human cerebral organoids recapitulate gene expression programs of fetal neocortex development. Proc Natl Acad Sci U S A. 2015; 112(51): 15672-7.

PubMed Abstract | Publisher Full Text | Free Full Text | F1000 Recommendation

90. Salter MW, Stevens B: Microglia emerge as central players in brain disease. Nat Med. 2017; 23(9): 1018-27. PubMed Abstract | Publisher Full Tex

91. F Russo FB, Freitas BC, Pignatari GC, et al:: Modeling the Interplay Between Neurons and Astrocytes in Autism Using Human Induced Pluripotent Stem Cells. Biol Psychiatry. 2018; 83(7): 569-78.

PubMed Abstract | Publisher Full Text | F1000 Recommendation 


\section{Open Peer Review}

\section{Current Peer Review Status:}

\section{Editorial Note on the Review Process}

Faculty Reviews are review articles written by the prestigious Members of Faculty Opinions. The articles are commissioned and peer reviewed before publication to ensure that the final, published version is comprehensive and accessible. The reviewers who approved the final version are listed with their names and affiliations.

\section{The reviewers who approved this article are:}

\section{Version 1}

\section{Laia Rodriguez-Revenga}

Biochemistry and Molecular Genetics Department, Hospital Clinic, Villarroel 170, Barcelona, Spain Competing Interests: No competing interests were disclosed.

\section{M. Chiara Manzini}

GW Institute for Neurosciences, Department of Pharmacology and Physiology, The George Washington University School of Medicine and Health Sciences, Washington, DC, USA

Competing Interests: No competing interests were disclosed.

\section{Alysson R. Muotri (iD)}

Department of Pediatrics/Rady Children $\square$ s Hospital San Diego, Department of Cellular \& Molecular Medicine, Stem Cell Program, School of Medicine, University of California San Diego, La Jolla, CA, USA Competing Interests: No competing interests were disclosed.

\section{Comments on this article}

\section{Version 1}

Reader Comment 23 May 2018

James Lyons-Weiler, Institute for Pure and Applied Knowledge, USA

"family and twin studies show that genetics contribute to the majority of the risk associated with ASD"

This is one interpretation, but it is incorrect on two counts. The majority of heritable studies actually show similar levels of contributed risk from genes and the environment, including those that did not measure any environmental factors. Since no studies have examined the role of environmental factors and genetic factors in the same populations, the significance of risk from genetic $x$ environment interaction has never been measured. Further attributing risk to genetics alone in heritability studies likely conflates heritable variation in brain attributes that are also heritable in the neurotypical population, and the overall genetic contribution is likely 
exaggerated. This would include neurological differences whose effects are altered in the presence of ubiquitous environmental toxins. By analogy, if everyone smoked, lung cancer would appear to be genetic.

Some of the heritability appears to be due to heritability of susceptibility to environmental toxins. The list of environmental toxins implicated by studies to date are numerous and varied, pointing to a cellular detoxification deficiency syndrome with altered metal detoxification, and, importantly, increased ER stress response and altered Unfolded Protein Response outcomes[1]. Autistics' have altered blood/brain and intestinal barrier functions[2], meaning they belong to a subset of people who cannot handle toxins from various sources as well as others.

We recently found that the FDA and the HHS both erred in their determination that the amount of aluminum in vaccines is 'safe' in the first six months of life [3]. Masson et al. (2018) similarly found flaws and unwarranted assumptions in two key studies[4]. "Genetic" interpretations of findings of signs of neurological difference in ASD prior to birth ignore the CDC's policy shift to promote vaccination during pregnancy[5]. This practice, which now involves thimerosal-containing flu vaccines, TdaP (primarily for pertussis), and others as needed [5] is conducted contra FDA approval and, in the case of pertussis, against product labeling. If mothers of children at risk of ASD also have cellular detoxification deficiency, the "genetic" aspect of ASD likely involves (partly) environmental susceptibility genes. Uptake of toxins from diet via a compromised gut lining, likely due to activated enteric microglia, will compound the effects of other sources of toxins.

The environmental susceptibility variation contributing ASD risk can include variation in proteincoding genes that alters their intrinsic disorder, making them more difficult to fold in the endoplasmic reticulum (ER), leading to genetically induced ER stress. Importantly, the protein or protein(s) involved can have any cellular function. Both thimerosal and aluminum cause ER stress, mitochondrial dysfunction, and impaired Golgi functions, all essential for proper cellular detoxification[1]. This means ASD individuals will tend to acquire a variety of types of toxins - and this has been observed, with levels predictive of severity of behavior [6].

The combined effects of genetic ER stress and environmentally induced ER stress is called ER Hyperstress[1], favoring ER overload (over reduction in transcription or translation), forcing the UPR to conclude via apoptosis independent of p53, release of cytokines, and re-distribution of toxins bound to cellular debris, which are picked up by macrophages which locate these metals to the periphery of the brain. Aluminum has been found in the brain of people with ASD[7].

Multiple chemical sensitivity is commonly reported in people with autism and is on the increase throughout the general population[8]. With ASD now estimated at 1 in 59, and 1 in 37 in boys [9], there is simply no plausible mechanism for a "mostly genetic" condition to appear within 1-1.5 generations,

For more citations on the cellular processes implicating environmental toxins via the ER Hyperstress/Cellular Detoxification Deficiency Model of ASD, see [10].

We can no longer afford to study $G$ alone, $E$ alone, and ignore $G \times E$ in ASD and other neurodevelopmental disorders. Future genetic studies should examine risk of environmental 
susceptibility in ASD, and include all sources of toxins.

[1] https://molecularautism.biomedcentral.com/articles/10.1186/s13229-016-0110-z

[2] https://www.omicsonline.org/peer-reviewed/pautism-is-an-acquired-cellular-detoxification-

deficiency-syndrome-with-heterogeneous-genetic-predispositionp-99314.html

[3] https://www.sciencedirect.com/science/article/pii/S0946672X17300950

[4] https://www.ncbi.nlm.nih.gov/pubmed/29307441

[5] https://www.cdc.gov/vaccines/pregnancy/pregnant-women/index.html

[6] https://www.nature.com/articles/srep26185

[7] https://www.sciencedirect.com/science/article/pii/S0946672X17308763

[8] https://www.ncbi.nlm.nih.gov/pubmed/20920818

[9] https://www.cdc.gov/media/releases/2018/p0426-autism-prevalence.html

[10] http://ipaknowledge.org/ASD-Causality-Model.php

Competing Interests: I have served as expert witness on various cases under consideration by the National Vaccine Injury Compensation Program, but none of those cases involve ASD or other neurodevelopmental disorders.

The benefits of publishing with F1000Research:

- Your article is published within days, with no editorial bias

- You can publish traditional articles, null/negative results, case reports, data notes and more

- The peer review process is transparent and collaborative

- Your article is indexed in PubMed after passing peer review

- Dedicated customer support at every stage

For pre-submission enquiries, contact research@f1000.com 